\title{
Ergonomics and simulation-based approach in improving facility layout
}

\author{
Jocelyn D. Abad' ${ }^{1}$ (I) \\ Received: 3 February 2017 / Accepted: 27 January 2018/Published online: 3 February 2018 \\ (c) The Author(s) 2018. This article is an open access publication
}

\begin{abstract}
The use of the simulation-based technique in facility layout has been a choice in the industry due to its convenience and efficient generation of results. Nevertheless, the solutions generated are not capable of addressing delays due to worker's health and safety which significantly impact overall operational efficiency. It is, therefore, critical to incorporate ergonomics in facility design. In this study, workstation analysis was incorporated into Promodel simulation to improve the facility layout of a garment manufacturing. To test the effectiveness of the method, existing and improved facility designs were measured using comprehensive risk level, efficiency, and productivity. Results indicated that the improved facility layout generated a decrease in comprehensive risk level and rapid upper limb assessment score; an increase of $78 \%$ in efficiency and $194 \%$ increase in productivity compared to existing design and thus proved that the approach is effective in attaining overall facility design improvement.
\end{abstract}

Keywords Efficiency $\cdot$ Ergonomics $\cdot$ Facility design $\cdot$ Safety $\cdot$ Promodel

\section{Introduction}

Strong market competition sets pressure on companies to streamline their processes and achieve overall operational efficiency. Several techniques are found effective in improving operational efficiencies such as work measurement, ergonomics, and facility design. Kazerouni et al. (2015) concluded that facility design is a major factor in efficiency. Previous studies have developed several approaches to improve and resolve facility design problems. One approach is the heuristic method which includes tabu search (TS), genetic algorithms (GA), ant colony, simulated annealing (SA) and hybrid approaches. However, these approaches are time-consuming and focus on material handling cost and distance improvements and do not incorporate actual setting and dimension of machines and equipment (Sharma et al. 2013; Dwijayanti et al. 2010). Another approach is the use of simulation software such as Promodel, Arena, Quest, and IGrip, which are a

Jocelyn D. Abad

jocelyn.delgado@tip.edu.ph

1 Department of Industrial Engineering, Technological Institute of the Philippines, Quezon City, Philippines more efficient and convenient method in evaluating facility layouts before implementation (Sharma et al. 2013).

Nevertheless, both heuristic method and simulation are not capable of addressing inefficiencies due to worker's health and safety. Therefore, it is critical not only to ensure the efficiency through facility design, but also to consider the health and safety of the employees (Kazerouni et al. 2015).

Mustafa et al. (2009) discussed that the primary purpose of ergonomics is to ensure a good fit between the employees and their job to optimize worker's comfort, safety and health, productivity and efficiency. Previous ergonomic studies have shown the relationship of workstation design in worker's efficiency and safety. Shewchuk et al. (2017) provided a methodology in modeling and assessing the complex multi-worker physical processes which helped establish the ergonomic implications of the operations. Suhardi et al. (2016) improved the production process through ergonomic design. Other studies that applied ergonomics, workstation design and work system concepts include: the analysis on the effectiveness of the ergonomic prototype in reducing risks associated in a task (Fonseca et al. 2016); identification of work-related musculoskeletal disorders (WMSDs) using ergonomic 
assessment tools such as rapid upper limb assessment (RULA) and rapid entire body assessment (REBA) (Sahebagowda et al. 2016) and the methodological framework incorporating technological and environmental factors to improve productivity and ergonomics in an assembly system design (Battini and Faccio 2011). Table 1 summarizes the common techniques in improving facility layout, its purposes and, drawbacks. Although both the heuristic method and simulation approaches produce optimal or best layout, these were not capable of addressing the health and safety issues of the workers.

Table 2 summarizes the previous developments in ergonomics and facility design. Several studies have focused on obtaining the optimal solution to solve facility layout problems, nevertheless have not considered the needs of workers. The goal of this study is to improve efficiency and productivity of the facility design and at the same time address inefficiencies caused by workers due to health and safety issues.

\section{Methodology}

Figure 1 illustrates the framework for improving facility layout through ergonomics and simulation-based approach. The methodology considers the variables related ergonomic risks, efficiency and productivity.

To measure the productivity and efficiency, this study incorporated Promodel simulation software both for the existing and improved layouts. Rapid upper limb assessment (RULA) (McAtamney and Corlett 2004) was used to determine the ergonomic risks in each process as well as Fuzzy Risk Predictive Model (McCauley-Bell and Badiru
1996) in determining comprehensive risk levels in the workstations.

\section{Results and discussions}

\section{Existing facility layout}

Process analysis revealed the delays in the operation specifically during the movement of the material. The cutter traveled around $28.39 \mathrm{~m}$ from sorting area to assembly area and vice versa. Moreover, from cutting operation, the worker traveled approximately $8.09 \mathrm{~m}$ going to sorting area. The existing layout did not show any concrete layout flow, which resulted in non-productive time due to the long distance traveled. Table 3 presents the simulation results of the existing facility layout.

Using RULA, most of the workstations fell under Class IV (investigate and implement change) category. This indicated that the workstations were prone to ergonomic hazards and risks, which may affect worker's performance and later on may result in musculoskeletal disorders (MSDs).

McCauley-Bell and Badiru (1996) developed the fuzzy predictive model to quantitatively predict the risk level of work-related musculoskeletal disorders (WMSDs). Three risk factors were identified namely: task-related, personal and organizational risks and were evaluated for relative significance. Levels of existence for each risk factor are the following: high (1.00), medium (0.50), low (0.20) and nonexistence (0.00). The $w_{n}, x_{n}$ and $y_{n}$ are relative weights for each factor and $a_{n}, b_{n}$ and $c_{n}$ are levels of existence for each factor. Relative weight for each risk factor is detailed in Table 4.

Table 1 Comparison of conventional techniques in improving operational efficiency

\begin{tabular}{|c|c|c|c|c|}
\hline \\
\hline \multicolumn{5}{|c|}{ 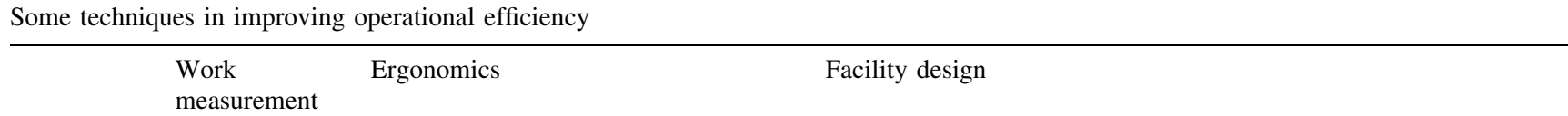 } \\
\hline $\begin{array}{l}\text { Tools/ } \\
\text { techniques }\end{array}$ & $\begin{array}{l}\text { Standard time } \\
\text { Charts }\end{array}$ & $\begin{array}{l}\text { Workstation analysis } \\
\text { Physical and environmental } \\
\text { assessments } \\
\text { Safety and work-related } \\
\text { musculoskeletal disorders (WMSDs) } \\
\text { assessments }\end{array}$ & $\begin{array}{l}\text { Heuristic methods } \\
\text { Genetic algorithm } \\
\text { Ant colony } \\
\text { Simulated annealing (SA) and } \\
\text { Hybrid approaches }\end{array}$ & $\begin{array}{l}\text { Simulation } \\
\text { Promodel } \\
\text { Arena } \\
\text { Quest } \\
\text { IGrip } \\
\text { Flexim } \\
\text { Witness }\end{array}$ \\
\hline Goal(s) & $\begin{array}{l}\text { Standardization } \\
\text { Efficiency } \\
\text { improvement }\end{array}$ & $\begin{array}{l}\text { Capable of addressing health and safety } \\
\text { issues of workers } \\
\text { Efficiency improvement }\end{array}$ & $\begin{array}{l}\text { Optimal layout } \\
\text { Efficiency improvement }\end{array}$ & $\begin{array}{l}\text { Best layout } \\
\text { Efficiency improvement }\end{array}$ \\
\hline Drawback(s) & $\begin{array}{l}\text { Process } \\
\text { focused }\end{array}$ & $\begin{array}{l}\text { Workstation and workplace } \\
\text { environment focused }\end{array}$ & $\begin{array}{l}\text { Time-consuming } \\
\text { Not capable of addressing health } \\
\text { and safety issues of workers }\end{array}$ & $\begin{array}{l}\text { Faster and convenient } \\
\text { Not capable of addressing health } \\
\text { and safety issues of workers }\end{array}$ \\
\hline
\end{tabular}


Table 2 Developments/published literature on ergonomics and facility design

\begin{tabular}{|c|c|}
\hline Title of paper and name of authors & Methodology \\
\hline $\begin{array}{l}\text { Simulation modeling and ergonomic } \\
\text { assessment of complex multi-worker } \\
\text { physical processes (Shewchuk et al. 2017) }\end{array}$ & $\begin{array}{l}\text { Discussed new method in a discrete simulation } \\
\text { of complex multi-worker physical processes, } \\
\text { for ergonomic and/or performance analysis }\end{array}$ \\
\hline $\begin{array}{l}\text { Productivity improvement of a manufacturing } \\
\text { facility using systematic layout planning } \\
\text { (Naqvi et al. 2016) }\end{array}$ & $\begin{array}{l}\text { Simplified the application of systematic layout } \\
\text { planning (SLP) in the development of a new } \\
\text { layout }\end{array}$ \\
\hline $\begin{array}{l}\text { Ergonomics study for injection moulding } \\
\text { section using RULA and REBA techniques } \\
\text { (Sahebagowda et al. 2016) }\end{array}$ & $\begin{array}{l}\text { Identified the work-related musculoskeletal } \\
\text { disorders (WMSDs) using rapid upper limb } \\
\text { assessment (RULA) and rapid entire body } \\
\text { assessment (REBA) techniques }\end{array}$ \\
\hline $\begin{array}{l}\text { Ergonomic checkpoints as the base of } \\
\text { stamping station work facilities } \\
\text { improvement (Suhardi et al. 2016) }\end{array}$ & $\begin{array}{l}\text { Developed ergonomic checkpoints as an } \\
\text { assessment tool for improving work } \\
\text { facilities }\end{array}$ \\
\hline $\begin{array}{l}\text { Integrating human factors and ergonomics in a } \\
\text { participatory program for improvements of } \\
\text { work systems: an effectiveness study } \\
\text { (Fonseca et al. 2016) }\end{array}$ & $\begin{array}{l}\text { Analyzed the effectiveness of the } \\
\text { implementation of a constructive measure } \\
\text { defined through a participatory ergonomic } \\
\text { program taking into account an ergonomic } \\
\text { evaluation and workers' perception about } \\
\text { risk factors related to task performance }\end{array}$ \\
\hline
\end{tabular}
facility layout planning (Kazerouni et al. 2015)

Optimal facility layout problem solution using genetic algorithm (Misola and Navarro 2013)

A comparative analysis of facility layout design and optimization techniques (Sharma et al. 2013)

New methodological framework to improve productivity and ergonomics in assembly system design (Battini and Faccio 2011)

A proposed study on facility planning and design in manufacturing process (Dwijayanti et al. 2010)

A genetic algorithm for layout problems in cellular manufacturing systems (Kulkarni and Shanker 2007)
Result and conclusions

Applied the proposed method in panelized residential construction and was able to provide a cost-effective result to reduce ergonomic risks, but the said method was found to be time-consuming

Proved the effectiveness of simplified SLP in increasing productivity of the layout

Used the results of RULA and REBA as inputs in redesigning workstations and reduce WMSDs

Improved the health and safety of the workers, and thus, increased their productivity

Ergonomic improvement and increased workers' satisfaction

Safer facility design (OHS) features in designing a facility layout

Developed a methodology that minimizes total material handling cost using genetic algorithm

Reviewed various facility layout design techniques

Developed a theoretical framework to assess a concurrent engineering approach to assembly systems design problems, in conjunction with an ergonomics optimization of the workplace

Assessed optimization techniques in facility layout

Used genetic algorithm to validate the performance of the quadratic assignment problems (QAP) implementation
The proposed method was more efficient than the four other compared methods and minimized material handling cost

Found out that simulation-based optimization technique was the suitable and preferable way of optimizing facility layout

Improved the assembly system layout configuration concerning both technological and environmental parameters

Found the limitations of heuristic methods, which were the following: time-consuming, cannot get the feel of the actual setting and actual dimension of the machine and equipment

Found out that simulation technique was a powerful tool in creating and evaluating the proposed layout design before

Obtained optimum solution for the problems selected

Problem 1 obtained the minimum cost with less computation

Problem 2 obtained better results than the reported in the literature

Problem 3, for small size problems, GA outperformed others but, for large size, it deviated from the global optimum 


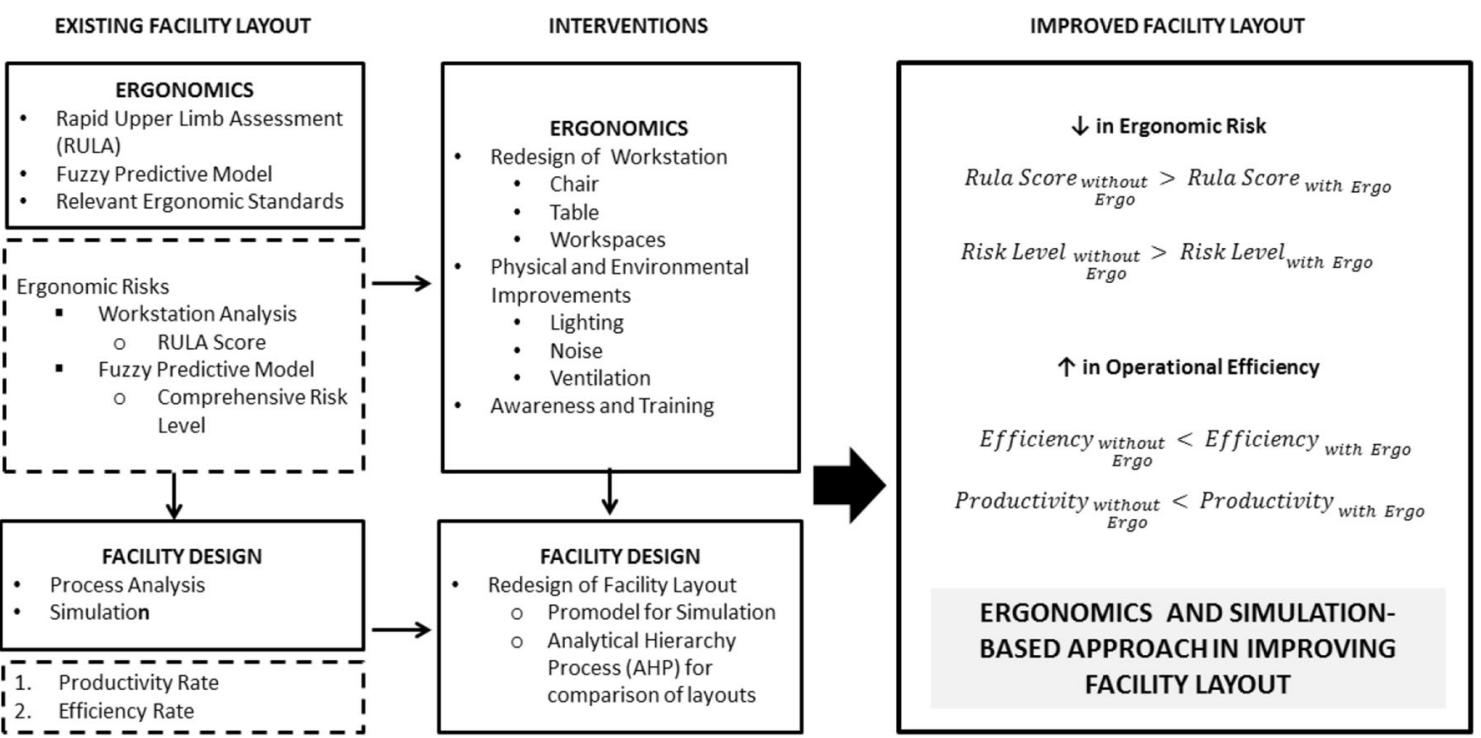

Fig. 1 Ergonomics and simulation-based approach in improving facility layout

Table 3 Existing facility layout summary

\begin{tabular}{ll}
\hline Existing layout & Result \\
\hline Total units produced & 51 units \\
Efficiency & $20.39 \%$ \\
Productivity & 1.70 units/worker per day \\
Total distance traveled by workers & $64.87 \mathrm{~m}$ \\
$\quad$ (in one cycle) &
\end{tabular}

\section{Task-related risk}

$R_{1}=a_{1} w_{1}+a_{2} w_{2}+a_{3} w_{3}+a_{4} w_{4}+a_{5} w_{5}+a_{6} w_{6}$

\section{Personal risk}

$R_{2}=b_{1} x_{1}+b_{2} x_{2}+b_{3} x_{3}+b_{4} x_{4}+b_{5} x_{5}+b_{6} x_{6}$

\section{Organizational risk}

$R_{3}=c_{1} y_{1}+c_{2} y_{2}+c_{3} y_{3}+c_{4} y_{4}+c_{5} y_{5}+c_{6} y_{6}+c_{7} y_{7}$

\section{Comprehensive risk level/index}

$Z=d_{1} R_{1}+d_{2} R_{2}+d_{3} R_{3}$

The computed overall comprehensive risk level for the existing workstations was 0.83 which was defined as a very

Table 4 Fuzzy predictive model risk factors and relative weights

\begin{tabular}{|c|c|c|c|c|c|c|}
\hline \multirow[t]{2}{*}{ Ranking } & \multicolumn{2}{|l|}{ Task-related } & \multicolumn{2}{|l|}{ Personal } & \multicolumn{2}{|l|}{ Organizational } \\
\hline & Risk factors & $\begin{array}{l}\text { Relative } \\
\text { weights }\end{array}$ & Risk factors & $\begin{array}{l}\text { Relative } \\
\text { weights }\end{array}$ & Risk factors & $\begin{array}{l}\text { Relative } \\
\text { weights }\end{array}$ \\
\hline 1 & $\begin{array}{l}\text { Awkward joint } \\
\text { posture }\end{array}$ & 0.299 & Previous CTD & 0.383 & Equipment & 0.346 \\
\hline 2 & Repetition & 0.189 & Hobbies and habits & 0.223 & $\begin{array}{l}\text { Production rate/ } \\
\text { layout }\end{array}$ & 0.249 \\
\hline 3 & Hand tool use & 0.180 & Diabetes & 0.170 & $\begin{array}{l}\text { Ergonomics } \\
\text { program }\end{array}$ & 0.183 \\
\hline 4 & Force & 0.125 & Thyroid problems & 0.097 & Peer influence & 0.065 \\
\hline 5 & Task duration & 0.124 & Age & 0.039 & Training & 0.059 \\
\hline 6 & Vibration & 0.083 & $\begin{array}{l}\text { Arthritis or degenerative joint disease } \\
\text { (DJD) }\end{array}$ & 0.088 & CTD level & 0.053 \\
\hline 7 & & & & & Awareness & 0.045 \\
\hline
\end{tabular}


Table 5 Mean levels of existence for each risk factor (existing workstations)

\begin{tabular}{|c|c|c|c|c|c|c|}
\hline \multirow[t]{2}{*}{ Ranking } & \multicolumn{2}{|l|}{ Task-related } & \multicolumn{2}{|l|}{ Personal } & \multicolumn{2}{|l|}{ Organizational } \\
\hline & Risk factor & Level & Risk factor & Level & Risk factor & Level \\
\hline 1 & Awkward joint posture & 1.00 & Previous CTD & 0.50 & Equipment & 1.00 \\
\hline 2 & Repetition & 1.00 & Hobbies and habits & 0.50 & Production rate/layout & 1.00 \\
\hline 3 & Hand tool use & 1.00 & Diabetes & 0.50 & Ergonomics program & 1.00 \\
\hline 4 & Force & 0.50 & Thyroid problems & 0.20 & Peer influence & 0.20 \\
\hline 5 & Task duration & 1.00 & Age & 1.00 & Training & 1.00 \\
\hline 6 & Vibration & 1.00 & $\begin{array}{l}\text { Arthritis or degenerative } \\
\text { joint disease (DJD) }\end{array}$ & 1.00 & CTD level & 1.00 \\
\hline 7 & & & & & Awareness & \\
\hline Numeric level for each category & 0.937 & & 0.5344 & & 0.915 & \\
\hline
\end{tabular}

Table 6 Recommended chair specifications

\begin{tabular}{|c|c|c|c|c|c|c|c|}
\hline \multirow[t]{2}{*}{ Ref } & \multirow[t]{2}{*}{ Chair specification } & \multirow[t]{2}{*}{ Anthropometric measurement } & \multicolumn{3}{|c|}{ Anthropometry } & \multirow[b]{2}{*}{ Male mean } & \multirow{2}{*}{$\begin{array}{l}\text { Recommended } \\
\text { chair specifications }\end{array}$} \\
\hline & & & $5 \%$ female & $95 \%$ male & Female mean & & \\
\hline A & Seat height & Popliteal height + shoe allowance & 14.17 & 18.5 & 16.88 & 18.08 & $14-18.5$ \\
\hline $\mathrm{B}$ & Seat depth & $\begin{array}{l}\text { Buttock-popliteal } \\
\text { length - clearance allowance }\end{array}$ & 10.75 & 15.47 & 12.77 & 13.27 & $10.75-15.47$ \\
\hline $\mathrm{C}$ & Seat width & $\begin{array}{l}\text { Hip breadth, sitting }+ \text { clothing } \\
\text { allowance }\end{array}$ & 12.2 & 16.14 & 14.83 & 14.52 & $15.00-16.54$ \\
\hline $\mathrm{D}$ & Backrest Height & Sitting height $\times 0.8$ & 25.16 & 28.97 & 25.17 & 26.72 & $25.00-28.97$ \\
\hline $\mathrm{E}$ & Backrest width & $\begin{array}{l}\text { Waist breadth (ANSI } \\
\text { standard }=11.81 \mathrm{~min})\end{array}$ & 13.39 & 19.4 & 15.84 & 17.59 & $16.00-19.4$ \\
\hline $\mathrm{F}$ & Backrest lumbar & None & 7.00 & 11.00 & $7.00-11.00$ & $7.00-11.00$ & $\begin{array}{l}7.00-11.00 \\
\text { Autofit technology }\end{array}$ \\
\hline G & Armrest height & $\begin{array}{l}\text { Elbow rest height } \\
\quad(\text { standard }=7.06-10.24)\end{array}$ & 7.06 & 10.24 & $7.06-10.24$ & $7.06-10.24$ & $7.06-10.24$ \\
\hline $\mathrm{H}$ & Armrest length & Standard $=10-12$ & 10 & 12 & $10.00-12.00$ & $10.00-12.00$ & $10.00-12.00$ \\
\hline I & $\begin{array}{l}\text { Distance between } \\
\text { armrests }\end{array}$ & $\begin{array}{l}\text { Hip breadth, sitting }+ \text { clothing } \\
\text { allowance }\end{array}$ & 12.2 & 16.14 & 14.83 & 14.52 & $15.00-16.54$ \\
\hline
\end{tabular}

high risk with individuals presently experiencing musculoskeletal irritation and/or medical correction. Haworth (2008) concluded that the ergonomically and adjustable designed chair with adequate personnel training decreased the occurrence of ergonomic risks, work-related disorders, and injuries and promoted an increase in productivity of around $17.7 \%$. An adjustable chair tied with proper office ergonomics orientation reduced musculoskeletal disorders (MSDs) growth over a period (Amick et al. 2003). Table 5 summarizes the mean levels of existence of each risk factor in the existing workstations.

\section{Interventions}

Several standards have been considered to enhance the workstation chair, along with the analysis and consideration of the local anthropometry standard. Common standards employ the 5th\%o female and 95th\%o male, which could accommodate $90 \%$ of the population. The Business and Institutional Furniture Manufacturer's Association Guideline (BIFMA Guideline 2002) is a common standard used in designing an ergonomically designed chair. Design parameters include seat height, seat depth, seat width, backrest height, backrest width, backrest lumbar, armrest height, armrest length, the distance between armrest and provision for the footrest. The BIFMA (2002) standard includes shoe allowance, clearance allowance, and clothing allowance, which are 1, 5 and 0.5 in., respectively. This study measured the anthropometric sizes using the local anthropometry standard (Del Prado-Lu 2006), in terms of mean, female 5th\%o, and male 95th\%o. Table 6 and Fig. 2 detail the revised chair specifications using anthropometry standard. 

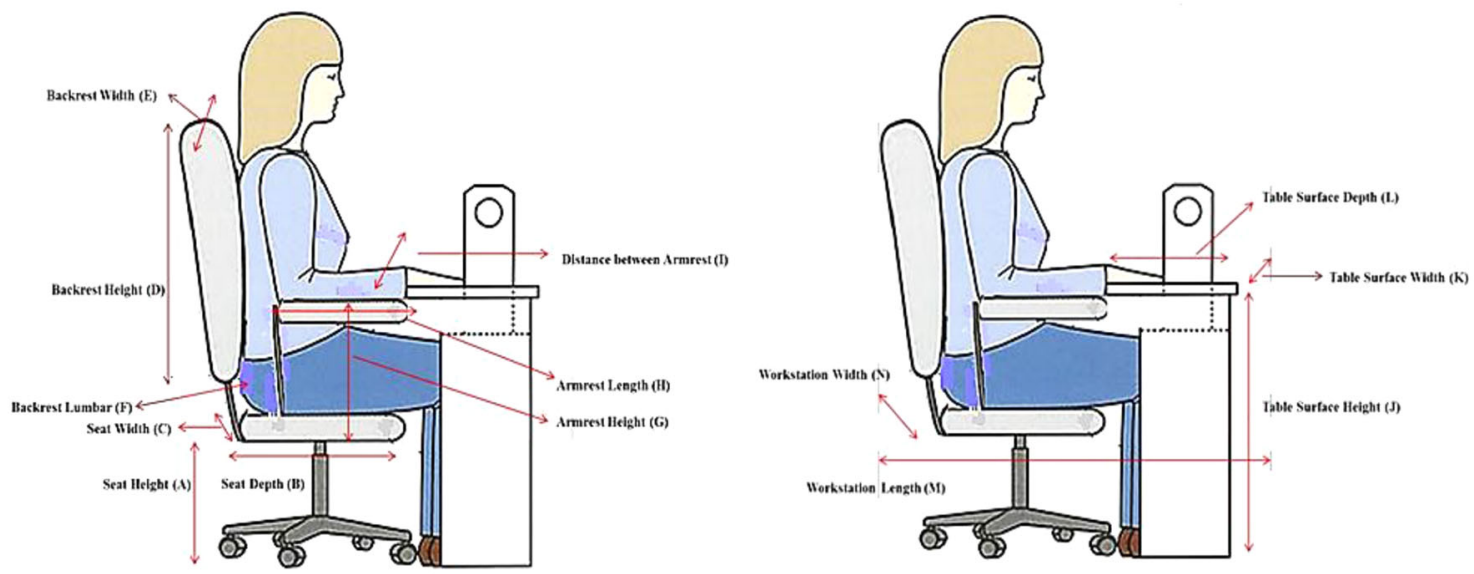

Fig. 2 Revised workstation chair and table

Table 7 Recommended workstation specifications

\begin{tabular}{|c|c|c|c|}
\hline Ref & $\begin{array}{l}\text { Workstation } \\
\text { specifications }\end{array}$ & Anthropometric measurement & $\begin{array}{l}\text { Recommended workstation } \\
\text { specifications }\end{array}$ \\
\hline \multirow[t]{2}{*}{$\mathrm{J}$} & $\begin{array}{l}\text { Table surface } \\
\text { height }\end{array}$ & $\begin{array}{l}\text { Minimum table height }=\text { seat height }+ \text { minimum } 5 \text { th\%o (female) of seating elbow } \\
\text { height }+ \text { shoe allowance }\end{array}$ & 27.56 \\
\hline & $\begin{array}{l}\text { Table surface } \\
\text { height }\end{array}$ & $\begin{array}{l}\text { Maximum table height }=\text { seat height }+ \text { functional elbow height }+ \text { shoe } \\
\text { allowance }\end{array}$ & 29.92 \\
\hline $\mathrm{K}$ & Table width & $\begin{array}{l}\text { Table width }=95 \text { th } \% \text { of hip breadth }(\text { male })+15 \% \text { clothing allowance }+15 \% \\
\text { clearance allowance }\end{array}$ & 16.97 \\
\hline \multirow[t]{3}{*}{$\mathrm{L}$} & Table depth & Acceptable distance reach & $11.00-14.00$ \\
\hline & $\begin{array}{l}\text { Forward reach } \\
\text { functional }\end{array}$ & 5th\%o (female) & 23.26 \\
\hline & $\begin{array}{l}\text { Forward reach } \\
\text { functional }\end{array}$ & 95th\%o (male) & 33.86 \\
\hline M & $\begin{array}{l}\text { Forward reach } \\
\text { functional }\end{array}$ & Actual table depth + seat depth & \\
\hline $\mathrm{N}$ & Arm span & 5th\%o (female)-95th\%o (male) & $55.51-71.26$ \\
\hline
\end{tabular}

Table 8 Mean levels of existence for each risk factors (improved workstations)

\begin{tabular}{|c|c|c|c|c|c|c|}
\hline \multirow[t]{2}{*}{ Ranking } & \multicolumn{2}{|l|}{ Task-related } & \multicolumn{2}{|l|}{ Personal } & \multicolumn{2}{|l|}{ Organizational } \\
\hline & Risk factors & Levels & Risk factors & Levels & Risk factors & Levels \\
\hline 1 & Awkward joint posture & 0.00 & Previous CTD & 0.00 & Equipment & 0.00 \\
\hline 2 & Repetition & 0.50 & Hobbies and habits & 0.00 & Production rate/layout & 0.00 \\
\hline 3 & Hand tool use & 0.20 & Diabetes & 0.50 & Ergonomics program & 0.00 \\
\hline 4 & Force & 0.20 & Thyroid problems & 0.20 & Peer influence & 0.00 \\
\hline 5 & Task duration & 0.50 & Age & 1.00 & Training & 0.00 \\
\hline 6 & Vibration & 1.00 & $\begin{array}{l}\text { Arthritis or degenerative } \\
\text { joint disease (DJD) }\end{array}$ & 0.00 & CTD Level & 0.00 \\
\hline 7 & & & & & Awareness & 0.00 \\
\hline Numeric level for each category & 0.2341 & & 0.1434 & & 0.00 & \\
\hline
\end{tabular}


Table 9 Criteria used in AHP

\begin{tabular}{lc}
\hline Criteria & Percentage $(\%)$ \\
\hline Efficiency & 35 \\
$\%$ in-operation time & 10 \\
In-system time & 15 \\
Material movement (distance traveled) & 10 \\
Productivity & 55 \\
$\%$ unit produced & 20 \\
Unit per worker per day & 20 \\
Total productive time & 15 \\
Resource utilization & 10 \\
Total & 100 \\
\hline
\end{tabular}

The sewing table along with the workspace was also calculated to suit the sizes and needs of the workers. Isamail (2013) detailed the calculation of table surface width and depth that would be appropriate to the workstation chair. The revised workstation specifications is summarized in Table 7.

The RULA of the improved workstation design including the chair, table, and workspaces rendered better score than the current design. The score of most of the operations in various workstations resulted in Class I (acceptable posture) category. This means that the improved workstation eliminated ergonomic risks among workers. Interventions improved the levels of existence of the risk factors and are summarized in Table 8.

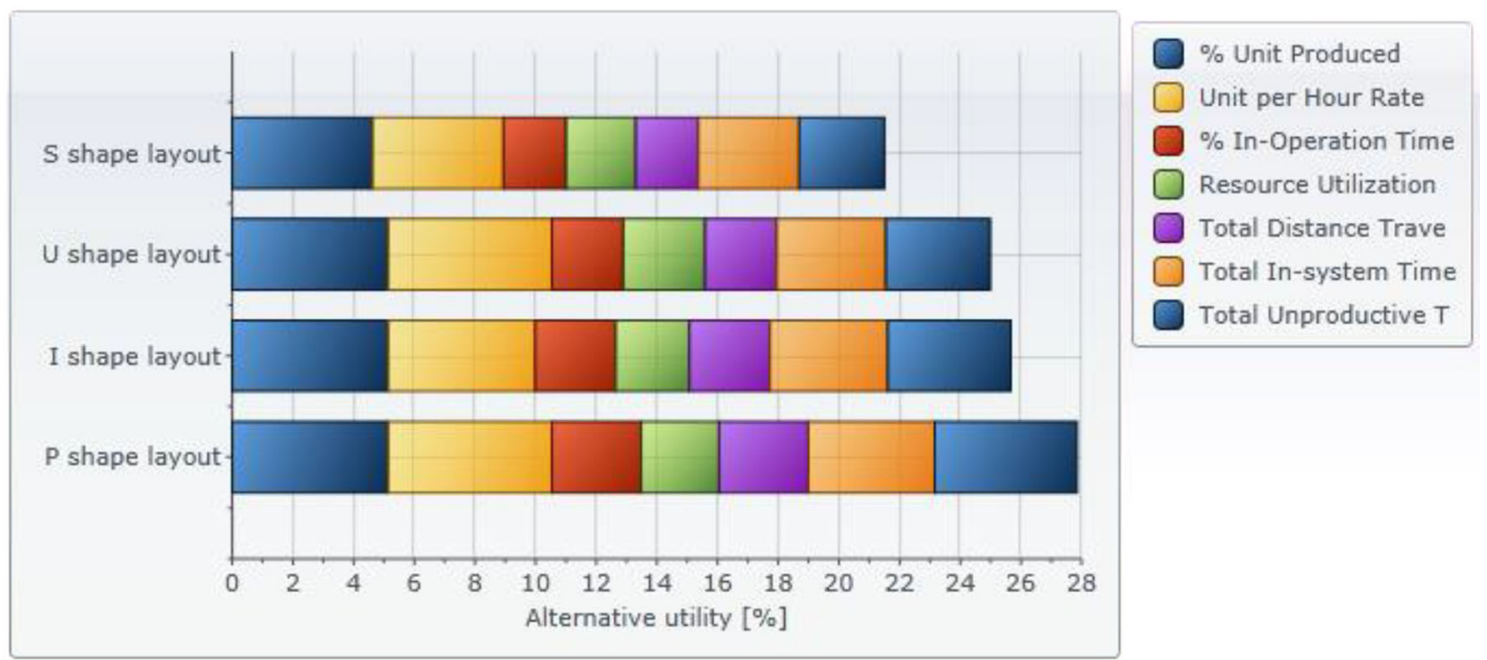

Fig. 3 AHP result of simulated facility layouts (redesigned)

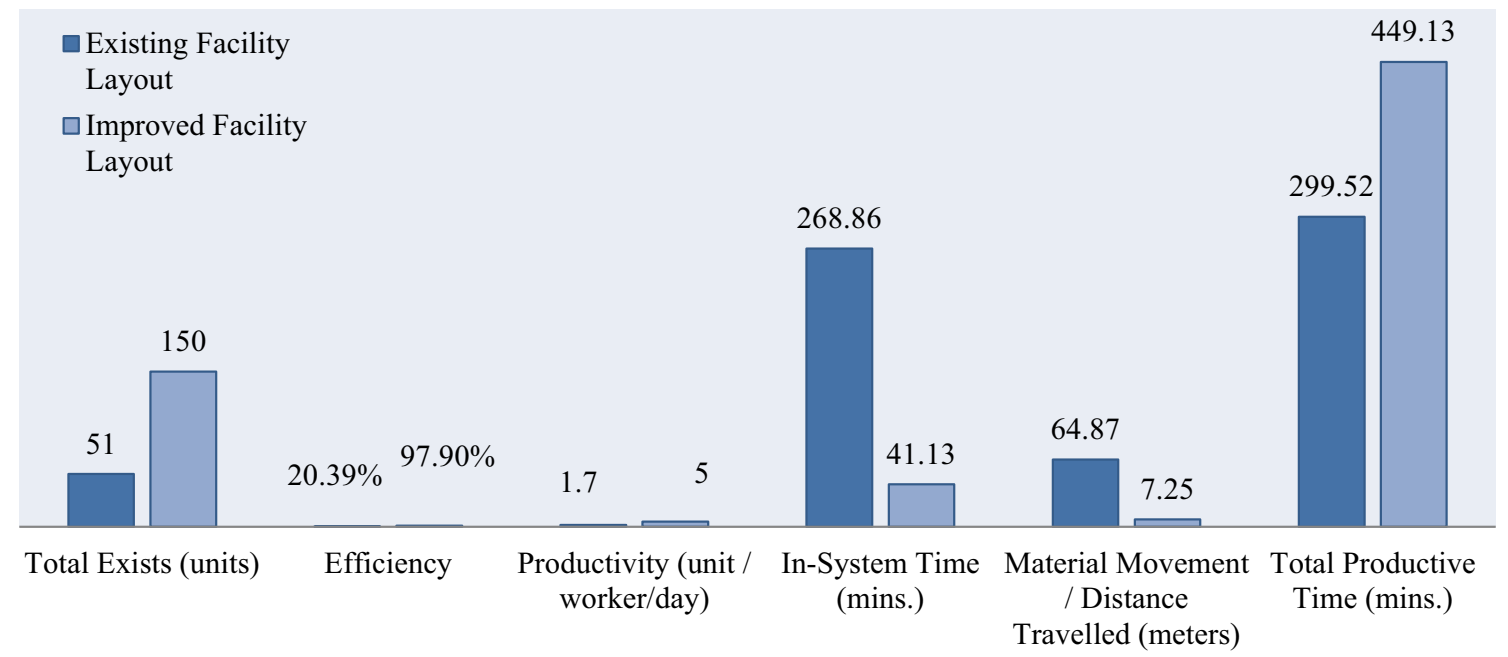

Fig. 4 Comparison of existing and redesigned facility layout 
Table 10 Summary of improvement

\begin{tabular}{lll}
\hline Criteria & Existing facility layout & Improved facility layout \\
\hline RULA score & Class IV (investigate and implement change) & Class I (acceptable posture) \\
Comprehensive risk level & 0.83 very high risk & 0.19 minimal risk \\
Efficiency & $20.39 \%$ & $97.90 \%$ \\
Productivity (unit produced/worker/day) & 1.70 & 5.00 \\
\hline
\end{tabular}

The computed overall comprehensive risk level for the improved workstations was 0.19 which was defined as minimal risk with individuals not experiencing any conditions that indicated musculoskeletal irritation. Both RULA score and comprehensive risk index decreased indicating more ergonomically designed workstation.

Other interventions were done such as the provision of pin light near workstation table, earplugs to protect workers from the harmful noise level, and additional exhaust fans to further improve the ventilation (OSHA 2001). Awareness and training programs for employees were also provided.

Since the inefficiencies caused by the worker due to their health and safety issues were addressed, redesign of facility layout through Promodel simulation followed. Using Analytical Hierarchy Process (AHP), the proposed layouts were evaluated using the following criteria. Table 9 details the percentages or relative weights of the criteria used in evaluating the proposed facility layouts. Relative weights were calculated based on the average response of company's stakeholders.

Figure 3 shows the AHP result of the simulated facility layouts. From the set criteria, it was found that the best among all simulated layouts was P-shaped. Figure 4 presented the graphs generated from AHP software that summarizes the comparison of simulated facility layouts.

Upon comparison, it showed that the redesigned layout improved the total units produced from 51 units to 150 units, increased the efficiency from 20.39 to $97.90 \%$ and decreased the total cycle time from 268.86 to $41.14 \mathrm{~min}$. Results indicated a $78 \%$ increase in efficiency and $194 \%$ increase in productivity compared to existing design and thus proved that the model is effective in improving overall operational efficiency and productivity. Table 10 summarizes the improvements in facility layout based on the RULA score, comprehensive risk level, efficiency and productivity.

\section{Conclusion}

Incorporating ergonomics in facility design simulation addressed the needs of the workers thereby eliminating, if not reducing associated risks to their health and safety and further increased efficiency and productivity. Results indicated that the improved layout generated a decrease in comprehensive risk level and rapid upper limb assessment (RULA) score; an increase of $78 \%$ in efficiency and $194 \%$ increase in productivity compared to existing design and thus proved that the approach is effective in attaining overall facility design improvement.

Open Access This article is distributed under the terms of the Creative Commons Attribution 4.0 International License (http://creative commons.org/licenses/by/4.0/), which permits unrestricted use, distribution, and reproduction in any medium, provided you give appropriate credit to the original author(s) and the source, provide a link to the Creative Commons license, and indicate if changes were made.

\section{References}

Amick et al (2003) Effect of office ergonomics intervention on reducing musculoskeletal symptoms. Spine 28(24):2706-2711

Battini, Faccio (2011) New methodological framework to improve productivity and ergonomics in assembly system design. Int $\mathbf{J}$ Ind Ergon 41:30-32

BIFMA International, Ergonomics Guidelines for VDT (Video Display Terminal) Furniture Used in Office Workspaces. Document G1 (2002)

Del Prado-Lu (2006) Anthropometric measurement of Filipino manufacturing workers. Int J Ind Ergon 37:497-503

DeRango et al (2003) The productivity consequences of two ergonomic interventions. Upjohn Institute Staff Working Paper No. WP03-95

Dwijayanti et al (2010) A proposed study on facility planning and design in manufacturing process. In: International multiconference of engineers and computer scientists 2010, vol III

Fonseca, Santos, Loureiro, Arezes (2016) Integrating human factors and ergonomics in a participatory program for improvements of work systems: an effectiveness study. In: Proceedings of the 2016 IEEE IEEM. 978-1-5090-3665-3/16: 1579-1583

Haworth (2008) The Ergonomic Seating Guide Handbook. Haworth Inc. http://media.haworth.com/asset/13337/Ergonomic_Seating_ Guide_Handbook.pdf

Isamail (2013) Anthropometric design of furniture for use in tertiary institutions in Abeokuta, South-western Nigeria. Eng Rev 33(3):179-192

Kazerouni et al (2015) Integrating occupational health and safety in facility layout planning, part I: methodology. Int J Prod Res 53(11):3243-3259. https://doi.org/10.1080/00207543.2014. 970712

Kulkarni, Shanker (2007) A genetic algorithm for layout problems in cellular manufacturing systems. In: Proceedings of the 2007 IEEE IEEM, 1-4244-1529-2/07: 694-698 
McAtamney, Corlett (2004) Rapid upper limb assessment (RULA). In: Stanton N, et al (eds) Handbook of human factors and ergonomics methods, chapter 7. Boca Raton, FL, pp 7:1-7:11

McCauley-Bell, Badiru (1996) Fuzzy modeling and analytic hierarchy processing - means to quantify risk levels associated with occupational injuries-part II: the development of a fuzzy rulebased model for the prediction of injury. In: IEEE transactions on fuzzy systems, vol 4. IEEE, New York, pp 132-138. https:// doi.org/10.1109/91.493907

Misola, Navarro (2013) Optimal facility layout problem solution using genetic algorithm. In: World Academy of Science, Engineering and Technology, International Journal of Mechanical, Aerospace, Industrial, Mechatronic and Manufacturing Engineering 7(8):1691-1698

Mustafa et al (2009) Ergonomics awareness and identifying frequently used ergonomics programs in manufacturing industries using quality function deployment. Am J Sci Res ISSN 1450-223X Issue 3(2009): 51-66
Naqvi, Fahad, Atir, Zubair, Musharaf Shehzad (2016) Productivity improvement of a manufacturing facility using systematic layout planning. Cogent Eng 3:1207296, 1-13

Occupational Safety and Health Administration (OSHA) (2001) United States Department of Labor. 200 Constitution Ave., NW, Washington, DC 20210

Sahebagowda, Kulkarni, Kapali (2016) Ergonomics study for injection moulding section using RULA and REBA techniques. Int $\mathbf{J}$ Eng Trends Technol 36:294-301

Sharma P, Phanden RK, Singhal S (2013) A comparative analysis of facility layout design and optimization techniques. AEMDS. https://doi.org/10.13140/2.1.1185.1524

Shewchuk et al (2017) Simulation modeling and ergonomic assessment of complex multiworker physical processes. IEEE Trans Hum Mach Syst 47(6):777-788

Suhardi et al (2016) Ergonomic checkpoints as the base of stamping station work facilities improvement. In: 2nd international conference of industrial, mechanical, electrical, chemical engineering (ICIMECE), 978-1-5090-4161-9/16: 136-141 